\title{
PENDUGAAN UMUR SIMPAN IKAN ASAP MENGGUNAKAN JENIS ASAP TEMPURUNG KELAPA DAN JENIS IKAN AIR TAWAR
}

\author{
Asep Dedy Sutrisno, Willy Pranata Widjaja, Wildan Qoharisma Salam \\ Program Studi Teknologi Pangan, Fakultas Teknik, Universitas Pasundan Jl. Dr. Setiabudi No. 193 Bandung 40153, \\ Indonesia \\ Email : asepdedysutrisno@unpas.ac.id
}

\begin{abstract}
The purpose of this research was to find out the shelf life of smoked fish produced from different types of freshwater fish, namely bawal fish, tawes fish and nilem fish using different types of coconut shell smoke, first grade liquid smoke, second grade liquid smoke and direct smoke.This research was conducted using Arrhenius Method on smoked fish using different coconut shell smoke and different freshwater fish species and stored at 25oC for 6 days. The responses in this research is organoleptic response (color, texture, flavour), microbiological response (Total Plate Count) and H2S test and Indol test. The method of this research consists of a preliminary research conducted to obtain a panelist acceptance limit on smoked fish products. The main research was conducted to find out the shelf life of smoked fish using different types of coconut shell smoke with different freshwater fish using microbial parameters also analyzed H2S test and Indol test to determine the overall quality degradation in smoked fish. Based on the parameters of total microbes treated using Arrhenius method, the shelf life of smoked fish was 5.75 days for bawal with garde 1 liquid smoke, 5.91 days for bawal with grade 2 liquid smoke and 3.97 days for bawal with smoke directly. For tawes with grade 1 liquid smoke that is 6.33 days, 3.90 days for tawes with grade 2 liquid smoke and 4.45 for tawes with direct smoke. Nilem fish with grade 1 liquid smoke is 5.72 days, 6.09 days for nilem with grade 2 liquid smoke and 4.25 day for nilem with direct smoke.
\end{abstract}

Keywords : Smoked Fish, Freshwater Fish, Coconut Shell Smoke, Shelf Life, Arrhenius Method.

\section{Pendahuluan}

Ikan air tawar memiliki banyak spesies atau jenis. Pada awalnya, ikan banyak hidup dan tersebar di berbagai perairan tawar, misalnya di sungai-sungai, rawa-rawa atau di danau-danau. Karena perkembangan peradaban manusia yang membuahkan ilmu pengetahuan dan teknologi, maka ikan-ikan yang tadinya hidup di perairan bebas banyak ditetaskan ke kolam budidaya. Pengembangan ikan air tawar di berbagai daerah di Indonesia sangat berpotensi. Banyaknya perairan ikan air tawar di Indonesia mendorong masyarakat untuk melakukan usaha budidaya ikan air tawar. Ikan yang banyak dibudidayakan di daerah-daerah tertentu adalah ikan bawal, ikan nila, ikan patin, ikan mas, ikan gurame, ikan nilem, ikan tawes dan lain-lain (Cahyono, 2000).

Pengasapan dapat membuat ikan yang diolah menjadi awet disebabkan oleh beberapa faktor, diantaranya berkurangnya kadar air, adanya senyawasenyawa asam di dalam kayu yang menghambat pertumbuhan mikroorganisme pembusuk, dan terjadinya koagulasi protein pada permukaan ikan yang mengakibatkan jaringan pengikat menjadi lebih kuat dan kompak sehingga tahan terhadap serangan dari mikroorganisme (Sulistijowati, 2011).
Asap cair merupakan hasil kondensasi dari pirolisa kayu yang terbentuk akibat proses pirolisis konstituen kayu. Proses pirolisis melibatkan berbagai proses reaksi yaitu dekomposisi, oksidasi, polimerisasi, dan kondensasi. Asap cair memiliki kemampuan untuk mengawetkan bahan makanan karena adanya senyawa asam, derivat fenol, dan karbonil (Darmadji, 1995). Berbagai komponen kimia tersebut dapat berperan sebagai antioksidan dan antimikroba serta memberikan efek warna dan citarasa khas asap pada produk pangan yang telah mengalami proses pengasapan. (Karseno. 2002).

Umur simpan merupakan periode waktu dimana bahan makanan masih dalam kondisi yang dapat diterima oleh konsumen atau layak dijual dibawah kondisi penyimpanan tertentu. Pendugaan masa kadaluarsa produk dapat diduga dengan cara matematik yang dihitung berdasarkan penurunan mutu produk dalam waktu tertentu. Ada beberapa metode yang bisa diaplikasikan untuk menduga masa kadaluarsa tersebut. Salah satu metode yang umum dipakai adalah menggunakan model Arrhenius yang umum digunakan untuk pendugaan masa kadaluarsa produk (Aliefah, 2016).

Tujuan dari penelitian ini adalah untuk mendapatkan hasil pemanfaatan asap tempurung 
kelapa sebagai bahan yang dapat memperpanjang umur simpan ikan air tawar serta untuk menetapkan jenis asap (asap langsung, asap cair grade I dan asap cair grade II) yang paling baik digunakan untuk memperpanjang umur simpan ikan air tawar dan menetapkan jenis ikan air tawar (ikan bawal, ikan nilem dan ikan tawes) yang paling baik umur simpannya ketika dimanfaatkan menjadi ikan asap.

Penelitian dimulai pada bulan Januari 2018, bertempat di Laboratorium Teknologi Pangan Fakultas Teknik Universitas Pasundan, Jalan Dr. Setiabudhi No. 193, Bandung.

\section{Bahan dan Metode}

Bahan baku yang digunakan adalah ikan bawal, ikan nilem dan ikan tawes yang diperoleh dari perairan Waduk Cirata. Bahan tambahan yang digunakan adalah tempurung kelapa, asap cair grade I, asap cair grade II yang diperoleh dari Toko Madaniah Yogyakarta, serta garam dapur dan air bersih. Bahan yang digunakan untuk untuk uji mikrobiologi adalah sampel ikan asap, Plate Count Agar (PCA) dan air steril.

Alat yang digunakan untuk proses penelitian ini adalah pisau, baskom plastik, timbangan digital, gelas ukur $100 \mathrm{ml}$, tungku pengasapan dan dryer. Alat-alat yang digunakan dalam analisis mikrobiologi adalah tabung reaksi, rak tabung, pipet $10 \mathrm{ml}$ dan $1 \mathrm{ml}$, filler, cawan petri, bunsen dan inkubator.

Metode penelitian yang dilakukan dibagi dalam 2 tahap yaitu penelitian pendahuluan dan penelitian utama.

Penelitian pendahuluan dilakukan untuk menentukan batas penerimaan panelis selama masa simpan ikan asap menggunakan uji organoleptik dengan metode uji hedonik terhadap atribut warna, aroma, tekstur dan kulit dari produk ikan asap dengan jumlah panelis sebanyak 30 orang.

Penelitian utama dilakukan untuk menentukan umur simpan ikan asap menggunakan uji mikrobiologi dengan metode angka lempeng total, yaitu menentukan jumlah mikroorganisme dalam ikan asap selama masa simpan. Data hasil uji mikrobiologi tersebut dihitung menggunakan pendekatan model Arrhenius. Kemudian dilanjutkan dengan uji $\mathrm{H} 2 \mathrm{~S}$ dan uji Indol untuk mengetahui penurunan mutu pada ikan asap secara menyeluruh.

\section{Hasil dan Pembahasan}

\subsection{Penelitian Pendahuluan}

Tujuan dari penelitian pendahuluan adalah untuk menentukan batas penerimaan panelis selama masa simpan ikan asap menggunakan uji organoleptik dengan metode uji hedonik terhadap atribut warna, tekstur dan aroma dari produk ikan asap dengan jumlah panelis sebanyak 30 orang.

Hasil organoleptik yang diujikan kepada 30 panelis, menunjukan bahwa rata-rata panelis tidak suka atau menolak sampel pada penyimpanan hari ke-6.
Tabel 1. Hasil Respon Organoleptik Ikan Asap

\begin{tabular}{|c|c|c|c|c|c|c|c|c|c|c|c|c|}
\hline \multirow{2}{*}{$\begin{array}{c}\text { Kode } \\
\text { Sampel }\end{array}$} & \multicolumn{10}{|c|}{ Hata - Rata Respon Panelis } \\
\cline { 2 - 14 } & $\mathbf{2}$ & \multicolumn{10}{|c|}{ Hari ke-0 } & \multicolumn{2}{|c|}{ Hari ke-2 } & \multicolumn{3}{|c|}{ Hari ke-4 } & \multicolumn{3}{|c|}{ Hari ke-6 } \\
\cline { 2 - 14 } & $\mathbf{W}$ & $\mathbf{T}$ & $\mathbf{A}$ & $\mathbf{W}$ & $\mathbf{T}$ & $\mathbf{A}$ & $\mathbf{W}$ & $\mathbf{T}$ & $\mathbf{A}$ & $\mathbf{W}$ & $\mathbf{T}$ & $\mathbf{A}$ \\
\hline $\mathrm{a}_{1} \mathrm{~b}_{1}$ & 3,00 & 3,20 & 3,07 & 2,87 & 3,07 & 3,07 & 2,30 & 2,67 & 2,57 & 1,57 & 1,90 & 1,83 \\
\hline $\mathrm{a}_{1} \mathrm{~b}_{2}$ & 3,60 & 3,53 & 3,50 & 2,97 & 3,13 & 3,50 & 2,23 & 2,40 & 2,57 & 1,90 & 1,67 & 1,90 \\
\hline $\mathrm{a}_{1} \mathrm{~b}_{3}$ & 4,93 & 5,00 & 4,83 & 4,37 & 4,33 & 4,83 & 3,37 & 3,20 & 3,30 & 2,93 & 2,23 & 2,27 \\
\hline $\mathrm{a}_{2} \mathrm{~b}_{1}$ & 3,10 & 3,27 & 3,17 & 2,73 & 2,70 & 3,17 & 2,27 & 2,57 & 2,47 & 1,77 & 1,73 & 1,73 \\
\hline $\mathrm{a}_{2} \mathrm{~b}_{2}$ & 3,70 & 3,67 & 3,83 & 3,20 & 3,37 & 3,83 & 2,40 & 2,87 & 2,43 & 1,60 & 1,83 & 1,53 \\
\hline $\mathrm{a}_{2} \mathrm{~b}_{3}$ & 4,80 & 4,43 & 4,70 & 4,47 & 3,70 & 4,70 & 3,07 & 3,20 & 3,03 & 2,53 & 2,23 & 2,07 \\
\hline $\mathrm{a}_{3} \mathrm{~b}_{1}$ & 3,16 & 3,23 & 3,27 & 2,90 & 2,63 & 3,27 & 2,57 & 2,43 & 2,50 & 1,87 & 1,70 & 1,77 \\
\hline $\mathrm{a}_{3} \mathrm{~b}_{2}$ & 4,13 & 4,17 & 4,40 & 3,83 & 3,40 & 4,40 & 2,70 & 2,77 & 2,53 & 1,83 & 1,83 & 1,50 \\
\hline $\mathrm{a}_{3} \mathrm{~b}_{3}$ & 4,56 & 4,60 & 4,50 & 4,13 & 3,63 & 4,50 & 3,03 & 3,13 & 3,03 & 2,27 & 2,60 & 2,17 \\
\hline
\end{tabular}

1. Warna

Berdasarkan hasil organoleptik dari produk ikan asap yang diujikan kepada 30 panelis terhadap atribut warna, menunjukan bahwa rata-rata panelis tidak suka atau menolak sampel ikan asap pada penyimpanan hari ke-6 karena terdapat perubahan yang signifikan dari atribut warna.

Menurut Winarno (1992) dalam Lharvinosa (2012) salah satu efek yang diperoleh dari hasil pengasapan adalah terjadinya pewarnaan (pencoklatan). Perubahan warna terjadi akibat berlangsungnya reaksi antara komponen fenol dalam asap dengan komponen protein dan gula dalam daging ikan. Selain itu juga terjadi rekasi maillard antara gugus amino dengan gula dalam daging ikan akibat proses pemanasan selama pengasapan.

Menurut Ruiter (1979) Pranata (2005) dalam Lharvinosa (2012), karbonil mempunyai efek terbesar pada terjadinya pembentukan warna coklat pada produk asapan. Fenol juga memberikan kontribusi pada pembentukan warna coklat pada produk asapan yang diasap meskipun intensitasnya tidak sebesar karbonil. Selanjutnya dijelaskan Ruiter (1979) dalam Atmaja (2009) bahwa komponen dari karbonil yang dapat meningkatkan terjadinya pencoklatan adalah glikoaldehid dan metilglioksal yang merupakan bahan pencoklat yang aktif dengan gugus amino.

Penggunaan asap cair pada penelitian tidak menghasilkan warna coklat yang signifikan seperti produk asapan pada umumnya. Warna coklat yang signifikan terjadi pada ikan yang diasap menggunakan asap tempurung kelapa secara langsung, panelis cenderung menyukai warna ikan asap yang diasap menggunakan asap langsung.

\section{Tekstur}

Berdasarkan hasil organoleptik dari produk ikan asap yang diujikan kepada 30 panelis terhadap atribut tekstur, menunjukan bahwa rata-rata panelis tidak suka atau menolak sampel ikan asap pada penyimpanan hari ke-6 karena terdapat perubahan yang signifikan dari atribut tekstur.

Penggunaan asap cair maupun asap langsung pada penelitian ini akan mengakibatkan tekstur ikan asap sedikit lebih keras, hal ini diakibatkan karena kemampuan asap cair atau asap langsung dalam 
mengikat air. Menurut Ginting, dkk (2014) penurunan kadar air ini dapat diakibatkan oleh kemampuan protein dalam mengikat air. Menurut Santoso (2006) dalam Ginting, dkk (2014) menyatakan bahwa semakin rendah kandungan protein, daya ikat air semakin rendah karena protein memiliki gugus hidrofilik yang dapat mengikat air.

Semakin lama penyimpanan pada suhu ruang maka nilai uji organoleptik tekstur ikan asap akan semakin menurun. Penurunan ini disebabkan oleh aktivitas air bahan pangan. Hal ini sesuai dengan pernyataan Santoso (2006) yang menyatakan bahwa penurunan tekstur juga disebabkan oleh aktivitas mikroorganisme yang mendegradasi protein menjadi senyawa yang lebih sederhana dan menyebabkan kemampuan protein untuk mengikat air semakin menurun. Penurunan daya ikat air dari protein tersebut menyebabkan tekstur menjadi lunak (Ginting, dkk. 2014).

\section{Aroma}

Berdasarkan hasil organoleptik dari produk ikan asap yang diujikan kepada 30 panelis terhadap atribut aroma, menunjukan bahwa rata-rata panelis tidak suka atau menolak sampel ikan asap pada penyimpanan hari ke-6 karena terdapat perubahan yang signifikan dari atribut aroma.

Menurut De mann (1989), pengujian aroma dalam suatu produk dianggap penting karena cepat memberikan hasil penilaian terhadap produk terkait diterima atau tidaknya suatu produk. Timbulnya aroma atau bau ini karena zat bau bersifat volatile (mudah menguap), sedikit larut dalam air dan lemak. Bahkan Bambang Kartika, dkk (1988) menyatakan bahwa aroma juga dapat dipakai sebagai suatu indikator terjadinya kerusakan pada produk, misalnya akibat dari pemanasan atau cara penyimpanan yang kurang baik ataupun adanya cacat (off flavour) pada suatu produk. Aroma yang dinilai dalam penelitian ini adalah aroma asap yang timbul karena penambahan asap cair maupun asap langsung.

Menurut Girad (1992) dalam Atmaja (2009) menyatakan bahwa aroma asap yang terbentuk sebagian besar dipengaruhi oleh adanya senyawa fenol dan karbonil serta sebagian kecil juga dipengaruhi oleh asam. Selanjutnya dijelaskna dalam Daun (1979), bahwa senyawa fenol yang berperan dalam pembentukan aroma asap adalah siringol. Siringol merupakan komponen dari fenol yang memiliki titik didih tinggi (Girard, 1992). Namun dalam penelitian Mahendra Dwi H (2008) dalam Atmaja (2009) menyatakan bahwa senyawa fenol yang berperan dalam pembentukan flavor asap adalah fenol dengan titik didih rendah.

\subsection{Penelitian Utama}

Penelitian utama dilakukan untuk menduga umur simpan ikan asap menggunakan uji mikrobiologi dengan metode angka lempeng total, yaitu menentukan jumlah mikroorganisme dalam ikan asap selama masa simpan pada suhu ruang. Data hasil uji mikrobiologi tersebut dihitung menggunakan pendekatan model Arrhenius.

Pada penelitian utama pengasapan ikan dilakukan menggunakan tiga jenis ikan air tawar yang berbeda oleh tiga jenis asap tempurung kelapa yang berbeda yaitu ikan bawal, ikan tawes dan ikan nilem diasap oleh asap cair grade 1, asap cair grade 2 dan asap langsung kemudian disimpan pada suhu 25oC selama 6 hari dan dilakukan pengujian secara mikrobiologis setiap dua hari sekali.

Penyimpanan dilakukan didalam inkubator yang bertujuan untuk menjaga suhu tetap konsisten pada 25oC. Penyimpanan dilakukan selama 6 hari dan pengamatan yang dilakukan selama 2 hari sekali yaitu hari ke-0, hari ke-2, hari ke-4 dan hari ke-6. Berdasarkan hasil penelitian pendahuluan, produk ikan asap mengalami penolakan oleh panelis pada hari ke-6 ditandai dengan adanya perubahan yang signifikan pada atribut warna, tekstur dan aroma.

Tabel 16. Hasil penentuan umur simpan ikan asap pada ikan air tawar dan asap tempurung kelapa yang berbeda dengan parameter mikroba pada suhu 25OC

\begin{tabular}{|c|c|c|c|c|c|}
\hline $\begin{array}{c}\text { Jenis } \\
\text { Ikan }\end{array}$ & Jenis Asap & Persamaan Regresi & $\mathbf{r}$ & $\begin{array}{c}\mathbf{k} \\
\text { (/hari) }\end{array}$ & $\begin{array}{c}\text { ts } \\
\text { (hari) }\end{array}$ \\
\hline \multirow{4}{*}{ Bawal } & Asap Cair 1 & $\mathrm{y}=4,79192+1,01663 \mathrm{x}$ & 0,97473 & 1,09 & 5,75 \\
\cline { 2 - 6 } & Asap Cair 2 & $\mathrm{y}=4,38352+1,08217 \mathrm{x}$ & 0,97631 & 1,09 & 5,91 \\
\cline { 2 - 6 } & Asap Langsung & $\mathrm{y}=4,06122+0,76534 \mathrm{x}$ & 0,984446 & 1,09 & 3,97 \\
\hline \multirow{4}{*}{ Tawes } & Asap Cair 1 & $\mathrm{y}=5,05033+0,97489 \mathrm{x}$ & 0,96967 & 0,91 & 6,33 \\
\cline { 2 - 6 } & Asap Cair 2 & $\mathrm{y}=5,23696+0,65422 \mathrm{x}$ & 0,96157 & 0,91 & 3,90 \\
\cline { 2 - 6 } & Asap Langsung & $\mathrm{y}=5,09704+0,64305 \mathrm{x}$ & 0,99097 & 0,91 & 4,45 \\
\hline \multirow{4}{*}{ Nilem } & Asap Cair 1 & $\mathrm{y}=5,13852+0,96538 \mathrm{x}$ & 0,97887 & 1,03 & 5,72 \\
\cline { 2 - 6 } & Asap Cair 2 & $\mathrm{y}=4,66282+1,03793 \mathrm{x}$ & 0,97778 & 1,03 & 6,09 \\
\cline { 2 - 6 } & Asap Langsung & $\mathrm{y}=4,37687+0,75938 \mathrm{x}$ & 0,99326 & 1,03 & 4,25 \\
\hline
\end{tabular}

Aspek mikrobiologi mempunyai peranan sangat penting dalam penilaian mutu produk pangan, karena beberapa jenis produk pangan cepat mengalami penurunan mutu akibat aktivitas mikroorganisme.

Penentuan umur simpan didasarkan pada faktor-faktor yang mempengaruhi umur simpan produk pangan. Faktor - faktor tersebut misalnya adalah keadaan alamiah (sifat makanan). Mekanisme berlangsungnya perubahan (misalnya kepekaan terhadap air dan oksigen), serta kemungkinan terjadinya perubahan kimia (internal dan eksternal). Faktor lain adalah ukuran kemasan (volume), kondisi atmosfer (terutama suhu), serta daya tahan kemasan selama transit dan sebelum digunakan terhadap keluar masuknya air, gas dan bau (Baturimba, 2011).

Pertumbuhan mikroba pada umumnya sangat tergantung dan dipengaruhi oleh faktor lingkungan, perubahan faktor lingkungan dapat mengakibatkan perubahan sifat morfologi dan fisiologi. Hal ini dikarenakan, mikroba selain menyediakan nutrien yang sesuai untuk kultivasinya, juga diperlukan faktor lingkungan yang memungkinkan pertumbuhan 
mikroba secara optimum. Beberapa faktor utama yang mempengaruhi pertumbuhan mikroorganisme meliputi suplai zat gizi, waktu, suhu, air, $\mathrm{pH}$ dan tersedianya oksigen. (Buckle, 1985).

Penguaraian bahan pangan oleh mikroorganisme dimulai dari penguraian karbohidrat, protein, kemudian lemak. Jika melihat terhadap bahan baku, ikan adalah komoditi yang mengandung cukup besar nilai nutrisi memungkinkan produk ikan asap ini merupakan produk yang cepat rusak.

Menurut Pelczar (2005), kebanyakan bahan pangan merupakan media yang baik bagi pertumbuhan mikroorganisme. Pada keadaan fisik yang menguntungkan, terutama pada kisaran $7^{\circ} \mathrm{C}-60^{\circ} \mathrm{C}$, organisme akan tumbuh dan menyebabkan terjadinya perubahan dalam hal penampilan, rasa, bau, serta sifatsifat lain pada bahan makanan.

Asap memiliki kemampuan untuk mengawetkan bahan makanan karena adanya senyawa asam, fenolat dan karbonil. Sehingga penggunaan asap serta penyimpanan ikan pada suhu rendah mampu menghambat pertumbuhan mikroba yang akan mampu mengurangi jumlah mikroba yang terdapat pada ikan (Harvinosa, 2012).

Senyawa fenol bersifat sebagai antioksidan, sehingga dapat menghambat kerusakan pangan dengan cara mendonorkan hidrogen sehingga efektif dalam jumlah sangat kecil untuk menghambat autooksidasi lemak yang dapat mengurangi kerusakan pangan karena oksidasi lemak oleh oksigen serta kandungan asam pada asap cair yang sangat efektif dalam menghambat dan mematikan mikroba dengan cara senyawa asam ini menembus dinding sel mikroorganisme yang menyebabkan sel mikroorganisme menjadi lisis kemudian mati, dengan menurunnya jumlah bakteri maka dapat meningkatkan umur simpan produk pangan (Putra, 2010).

Senyawa fenol merupakan salah satu senyawa kimia utama yang bersifat antibakteri (Sugiastuti, 2002). Sebagai antibakteri senyawa fenol ini memiliki mekanisme kerja dengan merusak struktur sel bakteri dan menghambat proses pembentukan dinding sel sehingga dapat menyebabkan lisis pada dinding sel bakteri, fenol juga akan menghambat pertumbuhan mikroba dengan cara mengganggu metabolisme dari mikroba dengan menghambat pembentukan spora dari mikroba tersebut (Susanti, 2006).

Ikan memiliki kadar air tinggi yaitu sekitar $80 \%$ dan $\mathrm{pH}$ yang mendekati netral sehingga merupakan media yang baik untuk pertumbuhan bakteri pembusuk maupun mikroorganisme lain, mengandung sedikit sekali tenunan pengikat (tendon) sehingga sangat mudah dicerna oleh enzim autolisis, daging ikan banyak mengandung asam lemak tidak jenuh yang sifatnya sangat mudah mengalami oksidasi (Afrianto dan Liviawaty, 1989).
Tabel 17. Hasil Uji H2S pada Ikan Asap yang disimpan pada suhu $250 \mathrm{C}$

\begin{tabular}{|c|c|c|c|c|c|}
\hline \multirow{3}{*}{ Jenis Ikan } & \multirow{2}{*}{ Jenis Asap } & \multicolumn{4}{|c|}{ Terbentuk $\mathrm{H}_{2} \mathrm{~S}$} \\
\cline { 2 - 6 } & & 0 & 2 & 4 & 6 \\
\hline \multirow{4}{*}{ Ikan Bawal } & Asap Cair 1 & - & - & + & + \\
\cline { 2 - 6 } & Asap Cair 2 & - & - & - & + \\
\cline { 2 - 6 } & Asap Langsung & - & - & - & + \\
\hline \multirow{4}{*}{ Ikan Tawes } & Asap Cair 1 & - & - & + & + \\
\cline { 2 - 6 } & Asap Cair 2 & - & - & + & + \\
\cline { 2 - 6 } & Asap Langsung & - & - & - & + \\
\hline \multirow{4}{*}{ Ikan Nilem } & Asap Cair 1 & - & - & - & + \\
\cline { 2 - 6 } & Asap Cair 2 & - & - & - & + \\
\cline { 2 - 6 } & Asap Langsung & - & - & - & + \\
\hline
\end{tabular}

Berdasarkan hasil percobaan uji $\mathrm{H} 2 \mathrm{~S}$ pada sampel ikan asap, maka dapat disimpulkan bahwa sampel ikan bawal dengan asap cair grade 1 terbentuk $\mathrm{H} 2 \mathrm{~S}$ pada penyimpanan hari ke 4 dan hari ke 6 , sampel ikan bawal dengan asap cair grade 2 dan sampel ikan bawal dengan asap langsung terbentuk $\mathrm{H} 2 \mathrm{~S}$ pada penyimpanan hari ke 6. Pada sampel ikan tawes dengan asap cair grade 1 dan ikan tawes dengan asap cair garde 2 terbentuk H2S pada hari ke 4 dan 6 , sampel ikan tawes dengan asap langsung terbentuk H2S pada hari ke 6. Pada sampel ikan nilem asap terbentuk $\mathrm{H} 2 \mathrm{~S}$ pada penyimpanan hari ke 6.

Pada percobaan uji $\mathrm{H} 2 \mathrm{~S}$ yang harus pertama dilakukan adalah dengan memotong ikan yang akan diuji sebesar biji kacang tanah atau jagung dan taruh dalam cawan petri, kemudian menutup dengan kertas saring yang telah ditetesi $\mathrm{Pb}$-asetat diatas kertas saring pada tempat dimana potongan daging diletakan. Selanjutnya yaitu menutup cawan petri dan biarkan sedikit terbuka, lalu tunggu sekitar 3-5 menit dan perhatikanterbentuknya warna coklat pada bekas tetesan Pb-asetat. Jika terbentuk warna coklat hal tersebut menandakan adanya $\mathrm{H} 2 \mathrm{~S}$ dari hasil pembusukan ikan,

Hidrogen Sulfida (H2S) terbentuk melalui reaksi sebagai berikut:

$\begin{array}{lll}\text { Cystin } & \rightarrow & 2 \text { Cistein } \\ 2 \text { Cistein } & \rightarrow & \mathrm{H} 2 \mathrm{~S}+\mathrm{NH} 3+\mathrm{CH} 3 \mathrm{COOH} \\ \mathrm{H} 2 \mathrm{~S}+\mathrm{PbAc} & \rightarrow & \mathrm{PbS}(\text { hitam })+\mathrm{CH} 3 \mathrm{COOH}\end{array}$

Hidrogen Sulfida (H2S) adalah molekul gas yang bersifat racun, terbentuk melalui pemecahan asamasam amino yang mengandung unsur sulfur atau belerang seperti cystin, cistein dan methionin. H2S bisa dijadikan sebagai indikator kebusukan pada makanan, khusunya pada makanan hewani yaitu daging. Jika suatu bahan pangan telah menghasilkan gas H2S maka bisa dibilang bahan pangan tersebut sudah tercemar atau tidak layak konsumsi, karena telah terurainya asam amino bergugus sulfur menjadi senyawa H2S.

Faktor yang mungkin terjadi apabila H2S tidak terbentuk pada sampel yang diuji yaitu ada zat pengganggu sehingga reaksi tidak berjalan sebagaimana mestinya, bakteri tidak dapat mengurai 
senyawa asam amino, sampel tidak mengandung asam amino bergugus sulfur atau pengujian kurang aseptis. Tabel 18. Hasil Uji Indol pada Ikan Asap yang disimpan pada suhu $25 \circ \mathrm{C}$

\begin{tabular}{|c|c|c|c|c|c|}
\hline \multirow{3}{*}{ Jenis Ikan } & \multirow{2}{*}{ Jenis Asap } & \multicolumn{4}{|c|}{ Terbentuk Indol } \\
\cline { 3 - 6 } & & 0 & 2 & 4 & 6 \\
\hline \multirow{4}{*}{ Ikan Bawal } & Asap Cair 1 & - & - & - & + \\
\cline { 2 - 6 } & Asap Cair 2 & - & - & - & - \\
\cline { 2 - 6 } & Asap Langsung & - & - & - & - \\
\hline \multirow{4}{*}{ Ikan Tawes } & Asap Cair 1 & - & - & - & + \\
\cline { 2 - 6 } & Asap Cair 2 & - & - & + & + \\
\cline { 2 - 6 } & Asap Langsung & - & - & - & - \\
\hline \multirow{4}{*}{ Ikan Nilem } & Asap Cair 1 & - & - & + & + \\
\cline { 2 - 6 } & Asap Cair 2 & - & - & + & + \\
\cline { 2 - 6 } & Asap Langsung & - & - & - & - \\
\hline
\end{tabular}

Berdasarkan hasil percobaan uji indol, maka dapat disimpulkan bahwa ikan bawal dengan asap cair grade 1 terbentuk indol pada penyimpanan hari ke 6, ikan bawal dengan asap cair grade 2 dan ikan bawal dengan asap langsung tidak terbentuk indol. Pada sampel ikan tawes dengan asap cair grade 1 terbentuk indol pada hari ke 6, ikan tawes dengan asap cair grade 2 terbentuk indol pada hari ke 4 dan 6, ikan tawes dengan asap langsung tidak terbentuk indol. Pada ikan nilem dengan asap cair grade 1 dan ikan nilem asap cair grade 2 terbentuk indol pada hari ke 4 dan 6 , ikan nilem dengan asap langsung tidak terbentuk indol.

Pada percobaan uji indol yang pertama harus dilakukan adalah membuat suspensi sampel dengan memotong ikan sebesar biji jagung kemudian dilarutkan menggunakan air steril pada cawan porselen lalu diencerkan dengan air steril pada tabung reaksi. Setelah itu inkubasi selama 48 jam pada suhu 37 oC. Kemudian beri 10 tetes reagen erlich dan amati perubahan yang terjadi. Jika terbentuk cincin merah pada permukaan larutan maka sampel tersebut positif membentuk indol. Indol adalah senyawa nitrogen yang dihasilkan dari degradasi triptofan oleh enzim triptofanase yang dibentuk oleh bakteri fekal. Bakteri yang tergolong bakteri fekal dapat memecah asam amino triptofan dan menghasilkan suatu senyawa berbau busuk yang disebut indol, dengan demikian bakteri yang dapat menghasilkan enzim pembentuk indol adalah Escherichia coli karena Escherichia coli berasal dari dalam usus manusia.

Reaksi terbentuknya indol adalah:

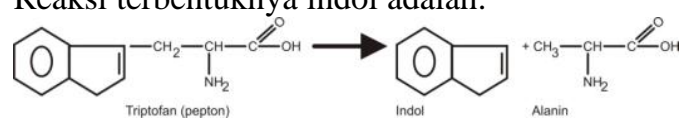

Gambar 13. Reaksi Indol

Indol + Erlich A $\rightarrow$ Resindol

Resindol + Erlich B $\rightarrow$ Cincin Merah

Produksi indol akan dideteksi dengan menggunakan pereaksi Erlich atau reagen Kovak. Indol akan bereaksi dengan aldehyde dalam reagen dan memberikan warna merah. Sebuah lapisan alkohol merah akan terbentuk seperti cincin di bagian atas menandakan indol positif. Hal ini pun menandakan sampel tersebut mengandung bakteri fekal atau Escherichia coli.

\section{Kesimpulan}

Berdasarkan hasil penelitian yang telah dilakukan, maka diperoleh kesimpulan sebagai berikut :

Hasil penelitian pendahuluan menunjukan bahwa batas penerimaan panelis terhadap seluruh sampel terjadi pada hari ke 6 dikarenakan terjadi perubahan yang signifikan terhadap atribut warna, tekstur dan aroma.

Berdasarkan parameter total mikroba yang diolah menggunakan pendekatan Arrhenius menggunakan ordo 1, dapat diketahui umur simpan ikan bawal yang diasap menggunakan asap cair grade 1 adalah 5,75 hari, ikan bawal yang diasap menggunakan asap cair grade 2 adalah 5,91 hari dan ikan bawal yang diasap menggunakan asap langsung adalah 3,97 hari. Selanjutnya yaitu ikan tawes yang diasap menggunakan asap cair grade 1 adalah 6,33 hari, ikan tawes yang diasap menggunakan asap cair grade 2 adalah 3,90 hari dan ikan tawes yang diasap menggunakan asap langsung adalah 4,45 hari. Sedangkan untuk ikan nilem yang diasap menggunakan asap cair grade 1 yaitu 5,72 hari, ikan nilem yang diasap menggunakan asap cair grade 2 adalah 6,09 hari dan ikan nilem yang diasap menggunakan asap langsung adalah 4,25 hari.

Berdasarkan hasil percobaan uji $\mathrm{H}_{2} \mathrm{~S}$ pada sampel ikan asap, maka dapat disimpulkan bahwa sampel ikan bawal dengan asap cair grade 1 terbentuk $\mathrm{H}_{2} \mathrm{~S}$ pada penyimpanan hari ke 4 dan hari ke 6 , sampel ikan bawal dengan asap cair grade 2 dan sampel ikan bawal dengan asap langsung terbentuk $\mathrm{H}_{2} \mathrm{~S}$ pada penyimpanan hari ke 6. Pada sampel ikan tawes dengan asap cair grade 1 dan ikan tawes dengan asap cair garde 2 terbentuk $\mathrm{H}_{2} \mathrm{~S}$ pada hari ke 4 dan 6, sampel ikan tawes dengan asap langsung terbentuk $\mathrm{H}_{2} \mathrm{~S}$ pada hari ke 6. Pada sampel ikan nilem asap terbentuk $\mathrm{H}_{2} \mathrm{~S}$ pada penyimpanan hari ke 6.

Berdasarkan hasil percobaan uji indol, maka dapat disimpulkan bahwa ikan bawal dengan asap cair grade 1 terbentuk indol pada penyimpanan hari ke 6 , ikan bawal dengan asap cair grade 2 dan ikan bawal dengan asap langsung tidak terbentuk indol. Pada sampel ikan tawes dengan asap cair grade 1 terbentuk indol pada hari ke 6, ikan tawes dengan asap cair grade 2 terbentuk indol pada hari ke 4 dan 6, ikan tawes dengan asap langsung tidak terbentuk indol. Pada ikan nilem dengan asap cair grade 1 dan ikan nilem asap cair grade 2 terbentuk indol pada hari ke 4 dan 6 , ikan nilem dengan asap langsung tidak terbentuk indol.

Berdasarkan hasil pendugaan umur simpan ikan asap mengacu pada identifikasi masalah dan hipotesis, maka jenis asap tempurung kelapa (asap cair grade 1, asap cair grade 2 dan asap langsung) dapat 
memperpanjang umur simpan ikan air tawar. Jenis ikan air tawar (ikan bawal, ikan tawes dan ikan nilem) memiliki umur simpan yang berbeda setelah diolah menjadi ikan asap.

\section{Daftar Pustaka}

1. Adawyah, R. 2008. Pengolahan dan Pengawetan Ikan. Bumi Aksara. Jakarta.

2. Badan Standardisasi Nasional. 2006a. SNI 012346-2006: Petunjuk Pengujian Organoleptik dan atau Sensori. Jakarta.

3. Badan Standardisasi Nasional. 2006b. SNI 012332.3-2006: Cara Uji Mikrobiologi - Bagian 3: Penentuan Angka Lempeng Total (ALT) pada Produk Perikanan. Jakarta.

4. Badan Standardisasi Nasional. 2009. SNI 2725.1:2009: Ikan Asap - Bagian1: Spesifikasi. Jakarta.

5. Badan Standardisasi Nasional. 2013. SNI 2725:2013: Ikan Asap dengan Pengasapan Panas. Jakarta.

6. Budijanto, S. (2008). Identifikasi dan Uji Keamanan Asap Cair Tempurung Kelapa untuk Produk Pangan. Jurnal Pasca Panen. 5(1), 3240.

7. Cahyono, B. 2000. Budidaya Ikan AIr Tawar. Kanisius. Yogyakarta.

8. Fardiaz, S. 1992. Mikrobiologi Pangan I. Gramedia Pustaka Utama. Jakarta.

9. Girard, J.P. 1992. Smoking in Technology of Meat Products. Clermont Ferrand. Ellis Horwood.

10. Kartika. 2011. Penanganan Ikan Segar. UI press. Jakarta.

11. Kottelat, M., J.A Whitten, N.S. Kartikasari and S. Wirjoatmodjo. 1993. Freshwater Fishes of Western Indonesia and Sulawesi. Dalhousie University. Canada.

12. Maretha, D.T. dan Shofia Nur Awami. 2011. Pengawetan Ikan Bawal dengan Pengasapan dan Pemanggangan. Mediagro. Vol 7. No. 2, 2011: Hal 33 - 47

13. Muratore, G., Mazzaglia, A., Lanza, C.M., Licciardello, F. 2007. Process variables on the quality of swordfish fillets flavored with smoke condensate. Journal of Food Processing and Presetvation.

14. Nelson, S.J. 2006. Fishes of the World. Wiley. Canada.

15. Nuraini, F. dan O. Nawansih. 2006. Uji Sensori. Buku Ajar. Universitas Lampung. Lampung.

16. Pertiwi., Mihada., Hartawan. 2015. Kualitas Kimia Fisik Bakso Ayam Yang Dimarinasi Dalam Asap Cair Dalam Waktu Yang Berbeda. E-journal.

17. Rasco, B. 2009. Smoking Fish at Home Safly. A Pacific Northwest Extension Publication. Washington State University.

18. Saanin, H. 1968. Taksonomi dan Kunci Identifikasi Ikan. Bina Cipta. Jakarta.
19. Setiawan, I. 1997. Pengawetan Ikan dengan Pencelupan dalam Asap Cair. Prosiding Seminar Teknologi Pangan 1997.

20. Subagja, J. 2006. Pelestarian Ikan Nilem (Osteochilus hasselti C.V) Melalui Teknologi Pembenihannya. Balai Riset Perikanan Budidaya Air Tawar. Bogor.

21. Sulistijowati, R. 2011. Mekanisme Pengasapan Ikan. Unpad Press. Bandung

22. Suyanto, S. R. 1999. Bawal. Penebar Swadaya. Jakarta.

23. Swastawati, F. 2008. Qualityand Safety of Smoked Catfish (riestal assinus) Using Paddy Chaff and Coconut Shell Liquid Smoke. Journal of Coastal Development. Vol. 12 No. 1. 47 - 55.

24. Syarief, R. 1993. Teknologi Penyimpanan Pangan. Arcan. Jakarta.

25. Tranggono, S., Setiadji, B., Darmadji, P., Supranto, dan Sudarmanto. 1997. Identifikasi asap cair dari berbagai jenis kayu dan tempurung kelapa. Jurnal Ilmu dan Teknologi Pangan. (2), 15-24. 